\title{
Preaching as a means to deconstruct the existence of apartheid discourses within the post-apartheid reformed tradition
}

\begin{abstract}
Critical discourse analysis is a discourse analytical research that studies the way social power are reproduced and resisted by text and talk in the social and political context. Racism and discrimination are discourses that have been a global problem since time immemorial. Australia, America, the United Kingdom and many countries in Europe have been considered much attuned to racism. Australia and North America's history have similarities with regard to the fact that they were inhabited by a group of 'foreign conquerors'. This set the pace of racism, distinguishing the conquerors as superior to the inferior conquered ones. Racism is not something outside of the individual or group but an internalised frame of reference. It has also, like social, political and religious ideas, systems of ideas shared by a social group. Since the early years of the South African history, the relationship between the black inhabitants and the white settlers (the rulers i.e. English, Dutch and later Afrikaans speaking people) has been characterised with white superiority and dominance over blacks. This class domination takes the form of "hegemony".
\end{abstract}

The author views discourse as a phenomenon that influences people's thoughts and acts by constituting what should be regarded as 'meaningful' and 'what should be ruled out'. Discourses create social knowledge in the minds of peoples and their way of interpretation of the world. In other words, discourses give meaning to the narratives that people live. Action is controlled by our minds. This article wishes to investigate the role of prominent people such as theologians in the reformed tradition in controlling the minds and actions of their members during apartheid and how preaching in a post apartheid era can contribute to eradicate existing apartheid discourse. Deconstruction is a "form of cultural, philosophical, social and textual critique designed to keep forms of discourse such as preaching from repressing otherness" (McClure 2007:19). Negative discourses that exist within a post-apartheid community in South Africa can be deconstructed in order to create positive narratives. This article reflects on preaching as a mechanism to deconstruct the existence of apartheid discourses in a post-apartheid dispensation.

'There are, in fact, white people who are racist and who are not naturally hateful but who have been captured by the customs, thinking and mores of the society in which they live' (Gordon 1997:137).

\section{INTRODUCTION}

Evidence of racism in the post-apartheid South Africa is a reality, this reminds of Joseph Brandt's statement that "while some gains resulted from the civil rights era... much is unquestionably worse" (McClure 2007:61). This article associates racism with discourse. The major work of discourse analysis is to look at a phenomenon such as racism as a complex system of social 
and political inequality that is reproduced by discourse in general and by "elite discourse" in particular (Van Dijk 2001:362). The concept 'discourse' provides a language for talking about a topic at a particular historical moment (Hall 1992:291). Discourse in this article refers to communicative events in oral as well as written form, as well as unwritten and unspoken ways of looking at "reality". This includes preaching, and for the purpose of this article, preaching to members of the Reformed traditions in a post-apartheid dispensation. Other forms of discourse are, e.g. professional discourse, bureaucratic discourse, medical discourse, educational and scholarly discourse, etc. (Van Dijk 2001:362). Discourse is regarding as the 'broad patterns of statements', which can be depicted in the communication of prominent members of society.

The ruling National Party of the apartheid era developed and implemented a political policy that was underpinned by an ideology based on racial differentiation. This ideology concurs with the dominant narratives of the Afrikaner as "His people". The 'dominant narratives' of the Afrikaner were underpinned by nationalistic ideals for the 'self'. These narratives created truth and meaning for the Afrikaner. Characteristic of dominant narratives are that they create truth and meaning within a cultural and social relational context. The discourse of the Afrikaner politicians, theologians and prominent members of society expressed during the apartheid years, created meanings which were stereotypical through their discursive themes. They succeeded in their discourses through literature and other forms of influential public communication, including preaching, to convince the Afrikaner that the values and beliefs of the whites were superior to those of all other races.

According to Van Dijk (2001:354), language users are social actors that have "personal and social cognition" which influence interaction and discourse of their individual members, whereas shared social representations govern the collective actions of a group. Goldberg (2002:59) stated that racists intend to exclude the racial 'others' with the goal in mind of domination or subjugation; of maximising profit by maintaining cheap labour force, by reserving jobs for members of what they take to be their own, etc. Boesak, as someone on the receiving end of racism during the apartheid era, stated that 'racism has brought dehumanisation, has undermined Black personhood, destroyed the human-beingness of those who are called to be children of God...their Blackness...calls forth such hatred' (Boesak 1984:113). Racism in South Africa can be regarded as a form of institutionalised domination by means of social, political and economic structures. It can also be regarded as a system of superiority based on colour, implemented by the National Party when the 'Afrikaners' came to power in 1948.

Racism is a complex phenomenon which should be regarded as an internalised frame of reference (De Wet 2001:99). For the purpose of this article it is important to note that racism is a discourse that directs the way people think about themselves (the 'self') and how they regard other races (the 'others'). During apartheid the major Reformed Churches and church leaders in South Africa, legitimised the apartheid government's ideology of apartheid by means of an apartheid theology. The apartheid ideology was underpinned by the Afrikaner's internalised frame of reference. The author is of the opinion that the latter was to a great extent contaminated by dominant narratives of the Afrikaner with regard to the 'others' and the impact of what Van Dijk called "social power" in terms of "control" (Van Dijk 2001:354). Prominent Afrikaner leaders in society (e.g. politicians and theologians) played a major role in keeping racism alive during the apartheid years. The discourse of the theologians during the apartheid years, contributed in a certain sense to legitimise the wrongs of the past. Public statements and sermons influenced the Afrikaner to inform their dominant stories and to rationalise the wrongs of an ideology and theology that exclude the racial 'others'. This concurs with the statement of Van Dijk (1997) and De Wet (2001) that people acquire mental models, social knowledge, attitudes and ideologies, which control their actions and dialogues with and about other racial 
groups by means of communication. The apartheid ideology and theology concur during the apartheid years with the majority of Afrikaners of what they regarded as 'acceptable thinking'. This is because it was on par with their internalised frame of reference which was kept alive by means of their dialogues with and about other racial groups which reminds of Van Dijk's (2001:354) statement on social acts of individuals that are constituent parts of group actions such as legislation or the reproduction of racism. This concurs also with the statement of De Wet (2001:99) that racism as an internalised frame of reference which has an impact on peoples' behaviour and their actions or deeds.

Racism served during apartheid to divide the South African population by means of the ruling party's ability to exercise their power to control. This reminds of Foucault's concept of bio power as a controlling mechanism of government with regard to processes which were exercised upon a mass of people (Guzylak-Shergold 2009:6). A fact is that racism is not natural or innate, but should rather be viewed as a result of the contamination of people by means of discourse. This article wishes to emphasise the role of discourse by especially those who control the minds and actions of others (Van Dijk 2001:355) as a means to express meanings, to influence people in producing racism and to influence them in such a way that it has an impact on their actions.

According to McClure (2007:19) deconstruction can refer to a variety of phenomena. McClure states that the concept deconstruction "can refer to a particular way the Bible is used in preaching" (McClure 2007:19). The argument in this article is that if Van Dijk's (2001:356) statement is true that the "elite" members and leaders of powerful social groups have control over types of discourse, the preacher in a post-apartheid context can contribute by means of preaching deconstructing the traces of racism. In other words, negative discourses, such as apartheid, can be deconstructed by utilising the text in preaching in order to create positive narratives. Therefore, preaching in the reformed tradition in South Africa, could be a mechanism of deconstructing the existence of traces of apartheid discourses which still exists in a post apartheid dispensation. The following section is a brief discussion on how discourse is involved in dominance and the production of social inequality with reference to the apartheid history in South Africa.

\section{DISCOURSE AND HISTORY}

The notion of discourse can be defined from a linguistic point of view as 'passages of connected writing or speech' (Hall 2004:346). An example in this regard is the discourse of the Afrikaner with regard to blacks which influenced to a great extent the way they perceived the 'others'. Foucault (Mautner 2000:204) describes the notion of discursive formation as a situation where the same discourse or state of knowledge appears as forms of conduct. Racism as a discourse and state of knowledge (white superiority) during the apartheid history of South Africa, leads to conducts that were condemned by many citizens of the country and the world.

Since the 18th century, the Cape Colony in South Africa was dominated by its white inhabitants who were determined to protect the barriers between whites and blacks. Differentiation on the basis of race in the 18th century Cape did not originate on the colonial frontier, but was deeply embedded in the white society long before the existence of a recognisable frontier. The notion to view blacks as the inferior race of the 'dark continent' and the white race as superior to the blacks is not unique to South Africa. This 'myth' is on par with the discourse of the white inhabitants of Europe since the 1800s (Salemink 1997). As early as 600 AD, Pope Gregory 1 taught that all men are equal in nature before God but that a hidden dispensation of providence produced a hierarchy of merit and rulership, his doctrine states that as a result of sin, different classes of men have been produced and these classes are ordained by divine justice. Foutz (2000:3) argues 
that this 'division of mankind into a hierarchy of rulership' led to a papal sanction for racism.

According to Foucault, discourse, knowledge and truth are concepts that are 'historicised', i.e. things are only true within the context of an identifiable period in history (Hall 2004:347). This is also evident in the work of Salemink (1997), 'De Afrikaanse Mythe'. This work describes the discourse of the European Catholic Church and its perception of blacks between 1867 and 1968. With reference to the discursive themes used in the Dutch Catholic Church's journals during the above-mentioned period, the black inhabitants of Africa were viewed as cannibals, as diabolical heathens, naïve children ('goedlachs kind'), the souls of Africa, holy heathens, the original culture, etc. Therefore history creates knowledge and truth relevant to a specific historical context. This knowledge may differ drastically from a specific period in history to a next. This reminds of Foucault's point of view that discourse, knowledge and truth are 'historicised' concepts. The following section reminds of Teun van Dijk's (2001:362) statement that racism is a complex system of social and political inequality that is reproduced by discourse in general and by elite discourses in particular.

\section{THE DOMINANT NARRATIVES OF THE AFRIKANER DURING APARTHEID}

The pre-First World War viewpoint of the Christians of the Dutch Catholic Church ranges from viewing themselves as people with a 'holy responsibility' and bearers of the 'light of the Christian civilisation' to Africa and the inhabitants of this 'dark continent' (Salemink 1997:27-28). This discourse of the Dutch Europeans concurs with the perception of the Afrikaner with regard to its role at the Southern tip of dark Africa prior to, as well as during, apartheid. This perspective reminds of the statement of Saint Isidore of Seville (ca.560-636) that there were people whom God regarded as unfit for freedom and therefore mercifully placed under slavery, the slaveholder has therefore a Divine calling (Foutz 2000:3). This 'truth' was what Rohman (2000:363) referred to as culturally determined constructions or concepts that are constructed through social interactions. It is also on par with the statement of Freedman and Combs with regard to the notion of 'narratives'. According to Freedman and Combs, narratives are constructed within cultural and social relational contexts, which form the basis of the development of truth and meaning (Freedman \& Combs 1996:31, 32). It is this 'meaning' and knowledge which stems from the Afrikaner's narratives or discourse that determined their conduct during the apartheid history.

A dominant narrative of the Afrikaner that determined their actions during the early years of apartheid is the Afrikaner's identification with the Old Testament's Israelites, as the people of the covenant and therefore 'His Chosen People'. This reminds of the common conviction of the American colonists that they possessed the calling of 'God's Chosen People' (Foutz 2000:5). Influential public discourse in South Africa in this regard constituted to a great extent what was regarded by the Afrikaner as meaningful and acceptable thinking. The author is of the opinion that the discourse and identification of the Afrikaner with the Old Testament people of the covenant may even be regarded as a reason why it was acceptable for some of the Afrikaners to allow forms of slavery in the early 1800s (Smith 1947:137-138). The American colonists of the South were of the opinion that by means of slavery the Africans' otherwise 'evil disposition' was both controlled and corrected, the notion of slavery was therefore regarded as a moral and caring practice (Foutz 2000:5). The tribes in Natal, according to Smith's biography of Daniël Lindley (Smith 1947), were sometimes found guilty of stealing the cattle of the cattle farmers in Natal, followed by so-called punitive expeditions by Boer commandos against them. During these expeditions, many orphans of blacks that were killed during these expeditions were captured and resettled as 'workers' on the Natal farms. 
The author is of the opinion that this was to many Afrikaner Christians an acceptable practice during the early 1800 s because it was on par with the identification of the Afrikaner with the Old Testament Israelites and their tradition of slavery. It served also a purpose in addressing the labour needs of the farmers during those years. This discourse and acceptable truth for the Afrikaner were constructed within a specific historical context. This concurs with the statement of Hall (2004:347) that things are only true within the context of an identifiable period in history. The entire idea of kidnapping children in order to invest in a future labour market may be an unacceptable practice amongst the majority of Christian Afrikaners today, because of the fact that discourse and 'truth' are concepts that are historicized.

\section{THE AFRIKANER AS HIS CHOSEN PEOPLE}

Perkins (2004:236) states that there can be no doubt that one of the most prominent aspects of the Christian narrative 'and one which has provided an excuse for the exclusion of the Jews, has been its association with the idea and mythology of nationalism, in particular, the claim that a nation has replaced the Jews as the Chosen People under the new Covenant of Christianity'. As already mentioned, a dominant narrative of the Afrikaner was (and in a certain sense is still) its identification with the Old Testament's Israelites as 'God's chosen people'. The quality of the relationship between many Afrikaners (those that regard a group of 'the Voortrekkers' at the Battle of Blood River as representative of the Afrikaner) and God grew deeper after the vow that was formulated on the eve of the battle. The victory of the Voortrekkers at Blood River was according to them a supernatural sign from God that he accepted and legitimised their idea of being his people. They therefore regarded the Afrikaners as a nation ('volk') that has a mandate and responsibility to play a specific role as Christians on the southern tip of Africa. To play that role demands from them to collectively remain united (and racially 'pure'), a belief that concurs with God's expectations of the Old Testament Israelites.

An example of a racist discourse as a product of socio-discursive praxis that emphasises the narrative of the Afrikaner as a nation that should stay 'racially pure' like the people of the covenant of the Old Testament is evident in the remarks of a prominent Afrikaner, Prof. G. Cronje during the 1940s (Cronjé 1947:75). According to Cronjé the Afrikaner developed what he called an 'instinct' during the course of the South African history not to give preferentiality to mixed marriages. It was discourses like this that influenced the Afrikaner's thoughts and the way they talked, reasoned and conducted themselves during the apartheid years. One of the missions of the white Afrikaner was therefore a constant battle to protect the 'white' race from extinction. Therefore Cronjé cautioned the white Afrikaners to refrain from miscegenation and warned the whites in South Africa of the dangers of the infiltration ('insypeling') of non-white blood and the dire consequences of such 'misdeeds' to the future of the white race (Cronjé 1947:82). This is one example of discourse that developed in the Afrikaner culture to what Zimmerman and Dickerson (1994:223) regarded as a 'dominant narrative'.

\section{THE IMPACT OF DISCOURSE: THE LEGITIMISATION OF THE APARTHEID IDEOLOGY}

As already mentioned, the role of theologians in the legitimisation of apartheid ideology with an apartheid theology should never be underestimated. The Afrikaner accepted these influential discourses as 'objective truths', because prominent theologians claimed publicly that the apartheid ideology was on a par with the message of the Bible. Only a small number of theologians within the reformed tradition, such as Prof. B.B. Keet strongly disagreed with, and were opposed to the hermeneutics of apartheid theologians (Brits 2006:42). Despite the efforts 
of a minority group of theologians and Afrikaners who rejected the apartheid ideology, the majority of Afrikaners accepted the dominant 'truth'. Weingarten (1995:9) stated that it is difficult to depart from discourse that has developed within a culture to the status of a 'dominant story'. This state of affairs also illustrates that reality and truth are culturally determined constructions. This explains how dominant stories influenced the majority of Afrikaners' thoughts by directing how they (the politicians, theologians and prominent leaders) talked and reasoned with regard to issues that concur with their internalized frame of reference.

The majority of Afrikaner theologians during apartheid expressed some degree of racialising within their discourses. The majority of them were influenced by the views of Abraham Kuyper who was a Dutch politician, journalist, statesman and theologian. He was the Prime Minister of the Netherlands between 1901 - 1905. Ministers and religious icons of the Reformed Church such as S du Toit and JD du Toit ('Totius'), and prominent theologians of the Dutch Reformed Church such as William Nicol and E.P. Groenewald (Cronjé 1947) can be viewed as scholars who were inspired by Kuyper's views and the discourse of the 'neo-Calvinist' (Brits 2000) or 'Kuyperian Calvinism' (Jonker 1989:26). Kuyper developed his theology against the background of French and German imperialism. In his work 'Antirevolutionaire Staatkunde' (Kuyper 1916: 494), God's diversification in creation is emphasised. This discourse formed the basis of the justification of apartheid as acceptable truth and the creation of an apartheid theology.

The discursive themes in the work of Kuyper's 'Het Calvinisme' (1898:28), presented the white race ('the self') positively while he perceived the black race ('the others') invariably negatively. This concurs with Van Dijk's (1993) statement that self-glorification in comparison with the 'others' is not unfamiliar with regard to acts of racism. As already mentioned, a feature of racism is the notion that hierarchies exist among humans - there is a clear distinction between the superior 'self' and the inferior 'other'. As an example, Kuyper explains the history of the 'blessed' families/tribe of Shem and Yaphet (not mentioning the blood of Ham - only that Ham did not receive the 'prophetical blessing'). This reminds of the theory that Noah's sons represented the three 'pigmentations' of humanity (Goldenberg 2003:145) i.e. Shem (the ruddy races - Shem the Akkadian samu - 'red'), Japhet (Heb. yaphet) and Ham (dark races). This concurs with the viewpoint of the early white inhabitants of North America, they argue that the three sons of Noah were the progenitors of the Black, Red and White races respectively (Foutz 2000:6). According to Goldenberg (2003:146), not one of these etymological suggestions is acceptable. JD du Toit (Totius), son of S. du Toit - a Reformed Church theologian who was, like his father, under the influence of Kuyper's views (Brits 2006; Kinghorn 1986) - refers to the savageness ('barbaarsheid') of Africa as a result of the curse of the tribe of Ham (Du Toit 1955:4). This is an attempt to claim that whereas Ham was cursed, people of colour are cursed. This claim utilises descriptive as well as prescriptive hermeneutics, drawing its claim directly from the historic narrative. These remarks can be regarded as a justification of a speaker or writer's prejudice.

$\mathrm{Du}$ Toit delivered a paper on Genesis one during a Congress of the Nation held in Bloemfontein in 1944, referring to God as the 'Skeidingsmaker' or 'Divider'. He collaborated with other theologians during the congress to justify apartheid ideas as norms that are in line with Scripture. These arguments were based on superficial hermeneutics (Kinghorn 1986:179) and are good examples of a discourse of justification. Such ideas were eventually institutionalised by the apartheid government (Amstutz 1995:6). Kuyper (1898:30) states that Calvinism kept to the 'set condition with regard to the mixing of the blood of nations'. These influential public discourses of elites and institutes such as the Reformed Churches influenced the Afrikaner theologians even prior to the apartheid regime in order to legitimise the ideology of separation by means of the establishment of an apartheid theology (Brits 2006; Du Toit 1944; Du Toit \& Du Toit 1955; Scholtz 1968; Cronjè 1947, and others). The 'absolute truths' (Du Toit 2000:57) 
discussed above formed the public discourse (oral and written forms) that dictated the way the majority of Afrikaners thought and acted. This is evident in the Dutch Reformed Church's missionary policy of 1935 (Loubser 1986:6; Pieterse 2000:8) which acknowledges the diversity of colour, culture and language groups, as well as numerous events such as the Volkskongres (Congress of the Nation) that was held in Johannesburg in 1947 (Cronjé 1947), the one in Bloemfontein (Amstutz 1995:6), the direction that Calvinistic preaching took (Fourie 1935: 262), and public statements by renowned leaders of the Reformed Church (Brits 2006; Du Toit 1954).

Social differentiation and spiritual and cultural segregation (exclusive nationalism) were officially acknowledged by the church, 'to the benefit of both sections' (Loubser 1988:14). According to Boesak (1984:111), 'racism became an essential part of an historical process of cultural, economic, political and psychological domination, and continues to manifest itself in all these areas'. The official mouthpiece of the Dutch Reformed Church, the Kerkbode, mentioned in 1948 that the church has always worked purposefully for the separation of races. In this regard, apartheid can rightfully be called a church policy (Boesak 1984:111). The question that Foutz $(2000: 8)$ asked with regard to the role of Western theology in the development of slavery is applicable : how could the church justify the duality '...to hold notions of God, Christ and salvation in the one hand while aggressively promoting and practicing oppression with the other.'

\section{PREACHING AND THE DECONSTRUCTION OF APARTHEID DISCOURSES}

Contextualising is a prerequisite for preaching in a post-apartheid context, the preacher should be aware and should take cognisance of the discourses that influence the way in which the hearer constructs his/her reality, knowledge and narratives (Brits 2009). Morrissey (1999) argued that the sermon as a discourse manifesting both socio-historical embeddedness and textuality, it is also an "event". Garner (2007:46) qualifies this concept by referring to the sermon as a communicative event i.e. it consisted of language used by a person (the preacher) in an attempt to affect the beliefs and behaviour of other people (the hearers) in a particular sociohistoric setting. It should be gospel-oriented communicative acts that constitutes the coming of God in his Word to human beings in their world through the communicative acts of human intermediaries with a view to spread and maintain Christian religious praxis (Pieterse, 1990:223). The discourse of the pulpit in a post-apartheid context should contrast with or draw upon contemporary discourses on existing racial issues.

Deconstruction as cultural, philosophical, social and textual critique, can keep forms of discourse such as preaching from repressing otherness (McClure 2007:19). Preaching can be utilised as communicative event to deconstruct these discourses. The history of racial South Africa proofs how public discourse was utilised as a mechanism to produce "objective truths". Preachers in the post-apartheid reformed tradition in South Africa should commit themselves to re-create society along biblical lines. By means of deconstruction, the excluded "other" is in fact present between the lines or in the margins of texts, cultures and societies (McClure 2007:19). Preachers should be able to listen to the text and it's "voice" and allows it to assert its point of view, to ask the right questions as an active participant in the hermeneutical process in order to bring out "the truth".

This is what the Scottish Reformers did during the Reformation, they re-constructed the nation, "spiritually, socially and economically by inculcating Gods Word into all from the lowliest to the sovereign" (Garner 2009:50). The preacher should guide the hearer with regard to his/ her usage of language (e.g. the metaphor in preaching), his/her theological and hermeneutic assumptions, to deconstruct evidence of racism, to avoid using the text to reinforce social power of one ethnical group over another. This guidance requires an approach that enables 
a preacher to inform his/her hearers of the "true doctrine" and the truths of the text. The preacher should guide the hearers by providing hermeneutic exposition of the text and from a New Homiletic point of view, to provide according to Vos (2005:297) "a lens through which the homiletician looks at life". The hearer should be guided "to be able to rediscover the tragedy of his/her own life in the sermon, not only cognitively, but also in an affective and participatory sense" (Vos 2005:297). The preacher can guide the hearer to depart from existing dominant racial narratives by means of participation in the making of the sermon and to implement the practical applications of the text as a homiletician by showing them how to act accordingly. The preacher should also listen to and learn more from people of colour in South Africa, the preacher should utilise this knowledge in developing sermons that "take up matters of race and ethnicity in the pulpit" (McClure 2007:61). The deconstructive eye and ear of the preacher and the hearer should uncover the traces and power of forces such as vested interests, self-promotion, exclusion and exploitation. Deconstruction will help the preacher and his congregation to observe and recognise "more clearly how behaviours, assumptions, uses of language, text, values, social practices and other matters benefit some individuals, groups and systems and how often it disbenefit others" (McClure 2007:69).

\section{CONCLUSION}

This article emphasises how the notion of racism is associated with discourse. The article shows how public and elite discourse played a vital role in the development of an apartheid ideology and the legitimisation of an apartheid theology. It demonstrates how the Afrikaner's dominant stories influenced the Afrikaner's public discourses during apartheid. It emphasises how the interpreter (e.g. preacher, prominent leader) of a text utilises his/her present knowledge as a source of prejudices and distortions that cause for misunderstanding of a text's meaning. It shows that discourse is more than simply oral or written forms of communication, but rather a powerful mechanism that can produce racism and the way the 'self' regards the 'others'. The power of public discourses as mechanisms to produce 'objective truths' may promote the selfpresentation in society at a cost to the 'others', as it happened during the apartheid years. In spite of the new political dispensation, the social and political transformation that took place since 1994, racism still forms part of the South African social fabric (De Wet 2001: 98). The mass media play a fundamental role in this reproduction of racism by utilising stereotypical themes in their discourse such as crime, immigration, cultural differences and cultural deviance such as 'backward' habits and racial tensions (De Wet 2001:99), which emphasises the power of (media) discourse (Van Dijk 2001:359).

The Reformed Churches should be sensitive and aware of the dominant discourses of the day and find effective ways to counteract any dominant discourses that keep racism within a postapartheid South Africa alive. It should ask questions such as: What is the role of the traditional Reformed Churches in eradicating racism? Are we aware of the dominant stories of the postapartheid Afrikaner and what is the role of the church in creating new stories that counteract racism? What is the truth that we preach today within the context of our dominant stories? How do we motivate today's believers that have their own internalised frame of reference to become more and more non-racial? How can we utilise preaching in our congregations in order to direct the opinion of our church members about themselves as a racial group and that of the 'others'? The church should therefore ask new questions with regard to issues such as race and gender, it should find new ways in the post-apartheid reformed church to move away and to replace its narrow nationalistic ideals and dominant discourses.

It should utilise mechanisms such as preaching and written communication to create a new 
dominant discourse in a new dispensation which will eradicate a tendency of continuously falling back on issues of ethnicity and gender. According to Van Dijk (2001:356) the leaders or "elites" of social groups and institutions have access to and control over types of public discourse. Professors control scholarly discourse, journalists control media discourse, teachers control educational discourse, etc. The reformed preacher in a post-apartheid era has therefore a major role to play as a leader that has control over the topics of his/her sermons and by influencing theological discourse.

The preacher and his congregation, as members of a new democratic South Africa, should ask themselves, what are the discourses, the acceptable truths, that underpin our perceptions and that determine our actions with regard to the 'others'? This not only a relevant question for the Afrikaner (reformed) churches but also for the black Christian churches, for the politicians of the day, for all members of the so-called 'rainbow nation' that regard themselves as collaborators in establishing internalised frames of reference that are conducive to the making of a new nonsexist and non-racist nation. Preaching can help to deconstruct the creation and the existence of negative discourses and to replace them with discourses that are on par with a sound and healthy horizontal and vertical relationship as advocated by the Epistle of James. According to Swanepoel (2003:150) deconstruction is a mechanism to empower people with "new voices". The reformed church should, by means of deconstruction in preaching, enable the new voices to "better conceive, articulate and organize its response to Christ's command that we love our neighbours as ourselves" (McKee 1989:8).

\section{REFERENCES}

Amstutz, Marc, R. 1995. Religion and politics in South Africa: Christian churches during the apartheid era. < http://www.jubileenow.com/papers/safricapap.html> ( September 7, 2005].

Brits, Hans, J. 2009. ' $n$ Postmoderne beskouing oor die teologiese legitimiteit van apartheid met verwysing na die veertigerjare van die vorige eeu. NGTT 42:1 \& 2, 40-49.

Boesak, Allan. 1984. Black and reformed: Apartheid, liberation and the Calvinist tradition. Johannesburg: Skotaville.

Cronjé, Geoffrey. 1947. Regverdige rasse-apartheid. Stellenbosch: CSV.

Du Toit, Ben. 2000. God? Geloof in 'n postmoderne tyd. Bloemfontein: CLF.

Du Toit, Jacob. D. 1955. Die godsdienstige grondslag van ons rassebeleid in Die Afrikaanse rassebeleid en die Skrif. Edited by Jacob, D, du Toit and Stephanus du Toit.eds. Potchefstroom: Pro Rege.

De Wet, Corene. 2001. A media discourse analysis of racism in South African Schools. <http://iej.cib.net> (August 10, 2010).

Fourie, Hermanus.C.M. 1935. Ons houding teenoor die naturel. Pages 256-263 in Koers in die krisis. Edited by Stoker, Hendrik.G. \& Frederick.J.M. Potgieter. Stellenbosch: Pro Ecclesia.

Foutz, Scott. 2000. Theology of slavery: Western theology's role in the development and propagation of slavery. Quodlibet. 2/1, 1-11.<http://www.quodlibet.net/articles/foutz-slavery.shtml>(January 27, 2011)

Freedman, John and Combs, G.1996. Narrative therapy: the social construction of preferred realities. New York: Norton.

Goldberg, David. 2002. The racial state. Oxford: Blackwell.

Goldenberg, David.M.2003. The curse of Ham. Princeton: Princeton University Press.

Gordon-Reed, Annette. 1997. Thomas Jefferson and Sally Hemings: an American controversy. Charlottesville: University Press of Virginia.

Guzyvlak-Shergold, Mark. 2009, Biopower and apartheid: the role of gold mining in South Africa's political economy. <http://markguzylakshergold.com>. (August 12, 2010).

Hall, Stuart. 1992. The west and the rest. In Formation of modernity. Edited by Hall, Stewart \& Gieben, B. Cambridge: Open University.

Hall, Stuart. 2004. Foucault and discours. In Social research methods. Edited by Seale, Charles. London: Routledge. 
Jonker, Willem.D. 1989. Selfs die kerk kan verander. Kaapstad: Tafelberg.

Kinghorn, Johann. 1986. Die NG Kerk en apartheid. Johannesburg: Macmillan.

Kuyper, Abraham. 1989. Het Calvinisme. Kampen: Kok.

Kuyper, Abraham. 1916. Antirevolutionaire Staatkunde: met nadere toelichting op ons program door Dr. A. Kuyper. Kampen: Kok.

Loubser, Johannes. A. 1987. The apartheid Bible. Cape Town: Maskew Miller Longman.

Mautner, Thomas.2002. The Penguin dictionary of philosophy. London: Penguin.

McClure, John, S. 2007. Preaching Words. Louisville: John Knox.

McKey, Elsie, Anne. 1989. The love office. The Reformed Journal. 39(11):7-9.

Perkins, Mary.A. 2004. Christendom and European identity: the legacy of a grand narrative. New York: Walter de Gruyter.

Pieterse, Hendrik.J.C. [s.a.] Ons ware profeet: die Christelike denke van Beyers Naudé, (the author has a copy of the manuscript).

Rohmann, Chris. 2000. The dictionary of important ideas and thinkers. London: Hutchinson.

Salemink, Theo. A. M. 1997. De Afrikaanse mythe. Kampen: Kok.

Scholtz, Gert.D. 1968. Die proses van gelykmaking. Johannesburg: Voortrekker.

Shein, Avital. 2004. A Foucauldian explanation of racism beyond Foucault's: Government and Politics. College Park: University of Maryland.

Smith, Edwin.W. 1947. Die lewe en tye van Daniël Lindley. Stellenbosch: NG Kerk.

Van Dijk, Teun. A. 1993. Analyzing racism through discourse analysis. Pages $92-134$ in Race and ethnicity in research methods. Edited by Stanfield, John.H. \& Dennis, R.M. London: Sage.

Van Dijk, Teun. A. 1997. Political discourse and racism : describing others in Western Parliaments. Pages 3-64 in The language and politics of exclusion. Edited by Riggins, Stephen. H. London: Sage.

Van Dijk, Teun. A. 2001. Critical discourse analysis. Pages 352-371 in Handbook of discourse analysis. Edited by Tannen, Deborah; Schiffrin, Deborah and Hamilton, Heidi. Oxford: Blackwell.

Weingarten, Kathy. 1995. Radical listening: challenging cultural beliefs for and about mothers. Pages 7-22 in Cultural resistance: challenging beliefs about men, women, and therapy. Edited by Kathy Weingarten. New York: Harrington Park Press.

Zimmerman, Jeff, L and Dickerson, Victoria. 1994. Using a narrative metaphor: implications for therapy and clinical practice. New York: Guildford.

\section{KEY WORDS}

Discourse

Racism

Apartheid ideology and theology

Deconstruct

Preaching

\section{TREFWOORDE}

Diskoers

Rassisme

Apartheidsideologie en teologie

Dekonstruksie

Prediking 